\title{
Esofaguectomía. Dilatación gástrica
}

\section{Esophagectomy. Gastric dilatation}

\section{Macías Guarasa*, E. Curiel Balsera y R. Olalla Sánchez}

\author{
Servicio de Cuidados Críticos y Urgencias, Hospital Carlos Haya, Málaga, España
}

Recibido el 13 de marzo de 2009; aceptado el 14 de abril de 2009 Disponible en Internet el 23 de septiembre de 2009

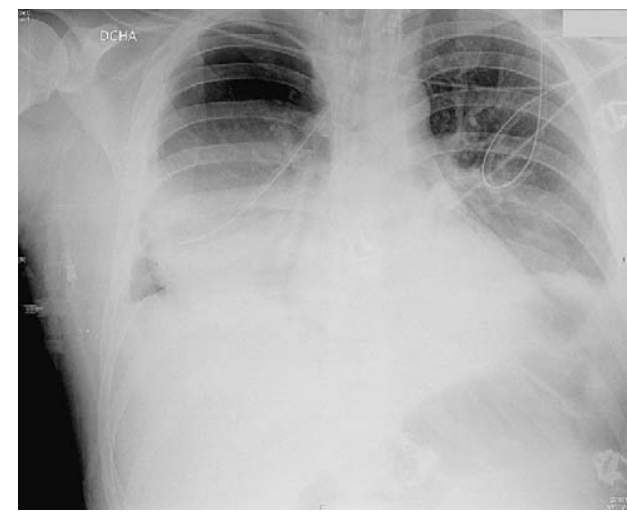

Figura 1 Cámara gástrica en el hemitórax derecho que simula un neumotórax.

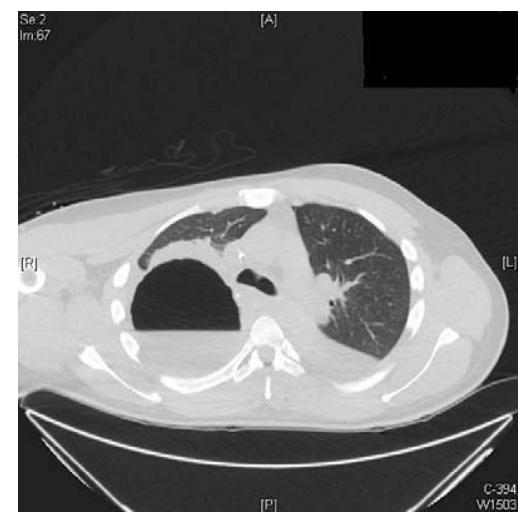

Figura 2 Cámara gástrica en el hemitórax derecho compatible con hidroneumotórax derecho.

Paciente con diagnóstico de carcinoma de esófago distal al que se le realiza disección transhiatal de esófago y curvatura menor gástrica, con anastomosis esofagogástrica. Su evolución es favorable. En la radiografía de tórax de control (fig. 1) se observa una hiperclaridad pulmonar superior que podría ser compatible con imagen de neumotórax derecho. Conociendo los datos clínicos y la cirugía descrita, tal diagnóstico se descarta; se trata realmente de la cámara gástrica (dilatada por exceso de aire, a pesar de la sonda nasogástrica colocada y que esta dilatación comprime el hemitórax derecho). No obstante y ante la duda, se realiza TAC torácica, en la que se observan los mismos hallazgos (fig. 2). En definitiva, destaca con este caso la relevancia de la historia clínica de un paciente, tan necesaria como las pruebas de imagen.

\footnotetext{
*Autor para correspondencia.

Correo electrónico: imaciasg@terra.es (I. Macías Guarasa).
} 